\begin{tabular}{l} 
JOURNAL OF EMPOWERMENT \\
VOL. 2, No. 1, Juni 2021, h. 139-149 \\
ISSN 2580-0620 (Print) \\
ISSN 2597-9809 (Online) \\
Available Online at https://jurnal.unsur.ac.id/index.php/JE \\
\hline \hline
\end{tabular}

\title{
PELATIHAN PARA SUPERVISI DI PT FASIC TENTANG KETENAGAKERJAAN DALAM MENYONGSONG REVOLUSI INDUSTRI 4.0.
}

\section{TRAINING OF SUPERVISORS AT PT FASIC ON EMPLOYMENT IN WELCOME TO THE INDUSTRIAL REVOLUTION 4.0.}

\author{
Ahmad Hunaeni Zulkarnaen \\ Universitas Suryakancana \\ ahmadhzul@gmail.com
}

Masuk : 15 Januari $2020 \quad$ Penerimaan : 05 Maret 2021

Publikasi : 01 Juni 2021

\begin{abstract}
ABSTRAK
Revolusi Industri 4.0 (RI 4.0) berpotensi meningkatkan kualitas hidup masyarakat di seluruh dunia, namun RI 4.0 telah menimbulkan kekhawatiran bahwa mesin-mesin suatu hari akan mengambil alih pekerjaan manusia, antara lain kemajuan kecerdasan buatan dan otomatisasi dapat menggantikan tenaga kerja manusia secara keseluruhan yang digantikan oleh teknologi robotik, digital dan otomatisasi (RI 4.0), hal ini berarti akan terjadi gelombang pengangguran dan pemutusan hubungan kerja (PHK) secara massal. Untuk menekan seminimal mungkin potensi negatif tersebut, perusahaan harus cepat tanggap dalam mengambil sikap demi menjaga kestabilan perusahaan salah satunya PT Fasic Indonesia harus meingkatkan kualitas keterampilan pekerja dalam menghadapi RI 4.0. Adapun metode yang digunakan dalam kegiatan tersebut perusahaan harus merencanakan, melaksanakan dan mengevaluasi hasil dari capaian yang ditargetkan. Tujuan dari pelaksanaan pelatihan diharapkan ketrampilan, keahlian, potensi kerja, produktivitas, disiplin, dan etos kerja) Supervisi di PT Fasic Indonesia dapat meningkat dan mengembang sesuai standar ilmu pengetahuan dan teknologi RI 4.0.
\end{abstract}

\section{Kata Kunci $\quad$ : Industri; Keterampilan; Pelatihan; Revolusi; Supervisi.}

\begin{abstract}
The Industrial Revolution 4.0 (RI 4.0) has the potential to improve the quality of life of people around the world, but RI 4.0 has raised concerns that machines will one day take over human jobs, including advances in artificial intelligence and automation that can replace the human workforce as a whole being replaced. By robotic, digital and automation technology (RI 4.0), there will be a wave of mass unemployment and layoffs (layoffs). To minimize this negative potential, companies must be responsive in taking a stance to maintain company stability, one of which is PT Fasic Indonesia, which must improve the quality of workers' skills in facing RI 4.0. As for the method used in these activities, the company must plan, implement, and evaluate the targeted achievements' results. The aim of the training is that skills, expertise, work potential, productivity, discipline, and work ethic are expected) Supervision at PT Fasic Indonesia can increase and develop according to the standard of science and technology RI 4.0.
\end{abstract}

Keywords $\quad$ : Industry; Skills; Training; Revolution; Supervision.

\section{A. PENDAHULUAN}

Pengertian "revolusi" berarti perubahan yang bersifat sangat cepat, pengertian "industri" adalah usaha pelaksanaan proses produksi. Pengertian "revolusi industri" adalah suatu perubahan yang berlangsung cepat dalam pelaksanaan dimana yang semula pekerjaan proses produksi itu dikerjakan oleh manusia digantikan oleh mesin, 
sedangkan barang yang diproduksi mempunyai nilai tambah (value added) yang komersial (Fonna, 2019).

Istilah "Revolusi Industri" diperkenalkan oleh Friendrich Engels dan Louis-Auguste Blanqui dipertengahan abad ke-19. Revolusi industri ini pun sedang berjalan dari masa ke masa. Dekade terakhir ini sudah dapat disebut memasuki fase ke empat (4.0) perubahan fase kefase memberikan perbedaan artikulatif pada sisi kegunaannya. Fase pertama (1.0) bertempuh pada penemuan mesin yang menitik beratkan (stressing) pada mekanisme produksi. Pada fase kedua (2.0) sudah beranjak pada etape produksi massal yang terintegrasi dengan quality control dan standarisasi. Fase ketiga (3.0) memasuki tahapan keseragaman secara massal yang bertumpu pada integrasi komputerasasi. Fase keempat (4.0) selanjutnya disebut RI 4.0, telah menghadirkan digitalisasi dan otomatisasi perpaduan internet dengan manufaktur (Fonna, 2019).

RI 4.0 adalah sebuah kondisi pada abad ke-21, ketika terjadi perubahan besarbesaran di berbagai bidang lewat perpaduan teknologi yang mengurangi sekat-sekat antara dunia fisik, digital, dan biologi. RI 4.0 ditandai dengan kemajuan teknologi dalam berbagai bidang, khususnya kecerdasan buatan, robot, blockchain, teknologi nano, komputer kuantum, bioteknologi, Internet of Thing, percetakan 3D, dan kendaraan tanpa awak (Fonna, 2019). Selanjutnya disebut teknologi RI 4.0.

Sebagaimana RI 4.0 berpotensi meningkatkan kualitas hidup masyarakat di seluruh dunia, namun RI 4.0 telah menimbulkan kekhawatiran bahwa mesin-mesin suatu hari akan mengambil alih pekerjaan manusia, antara lain kemajuan kecerdasan buatan dan otomatisasi dapat menggantikan tenaga kerja manusia secara keseluruhan yang digantikan oleh teknologi robotik, digital dan otomatisasi, hal ini berarti akan terjadi gelombang pengangguran dan PHK secara massal, termasuk di PT Fasic Indonesia. Untuk menekan seminimal mungkin potensi negatif tersebut, PT Fasic Indonesia yang akan memasuki era RI 4.0 harus memaksimalkan fungsi manajemen sumber daya manusia (SDM) dengan pengembangan pekerja melalui sarana pelatihan kerja.

\section{B. METODE}

Waktu pelaksanaan pengabdian ini berlokasi PT Fasic Indonesia, Kp. Pasir Manik RT.01/RW 05 Desa Selajambe Kec. Sukaliyu. Kabupaten Cianjur 43284, Jawa Barat Indonesia, dengan tema Pelatihan Para Supervisi di PT Fasic Indonesia Berdasarkan Undang-Undang Nomor 13 Tahun 2003 tentang Ketenagakerjaan Dalam Upaya Menyongsong Revolusi Industri 4.0.

Adapun metode yang digunakan dalam pelaksanaan pengabdian ini, yaitu sebagai berikut :

\section{Diagram 1 Metode Pelaksanaan Pengabdian}

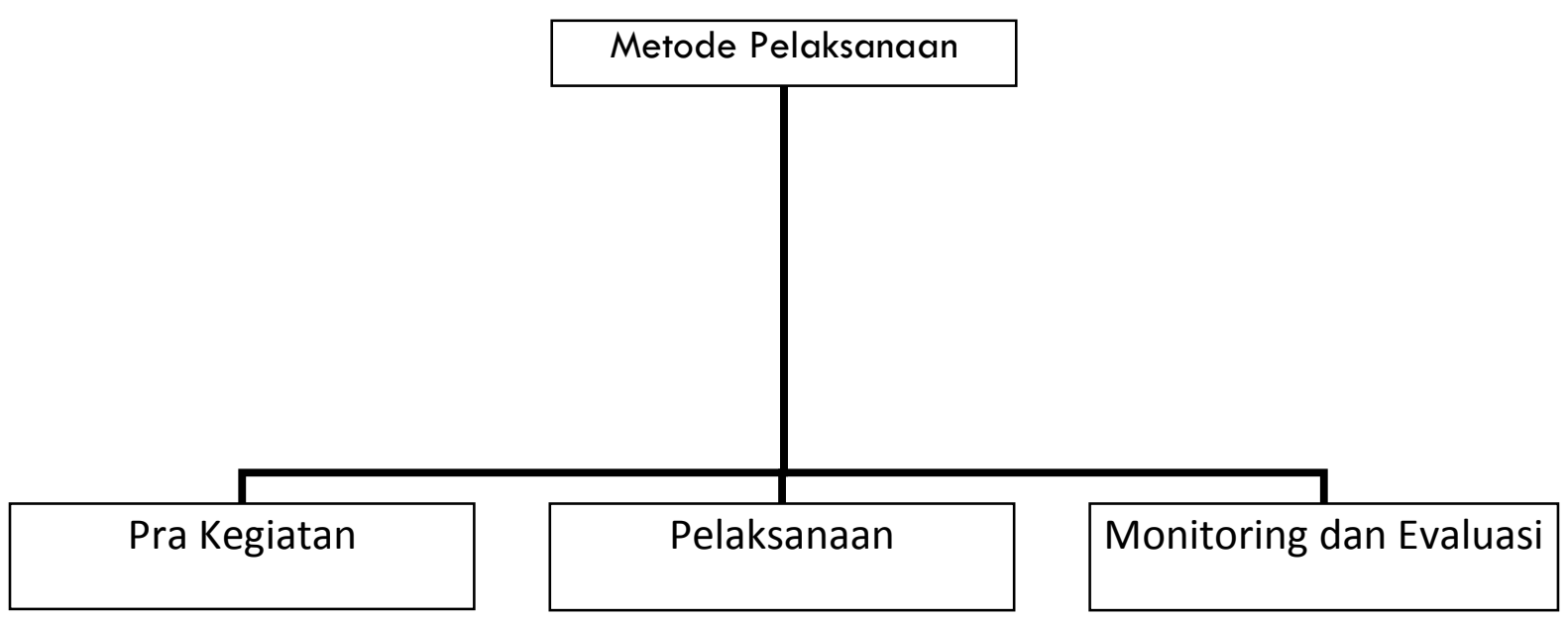




\section{HASIL ATAU PEMBAHASAN}

1. Pra Kegiatan Pelatihan Keterampilan Pekerja dalam menghadapi RI 4.0. di PT Fasic Indonesia

Berdasakan pengamatan penulis mengenai RI 4.0, pada kondisi abad ke-21 (dua puluh satu) terjadi perubahan besar-besaran di berbagai bidang lewat perpaduan teknologi yang mengurangi sekat-sekat antara dunia fisik, digital, dan biologi. RI 4.0 ditandai dengan kemajuan teknologi dalam berbagai bidang, khususnya kecerdasan buatan, robot, blockchain, teknologi nano, komputer kuantum, bioteknologi, Internet of Thing, percetakan 3D, dan kendaraan tanpa awak, yang menimbulkan kekhawatiran bahwa mesin-mesin suatu hari akan mengambil alih pekerjaan manusia, antara lain kemajuan kecerdasan buatan dan otomatisasi dapat menggantikan tenaga kerja manusia secara keseluruhan yang digantikan oleh teknologi robotik, digital dan otomatisasi (RI 4.0), maka penulis bekerja sama dengan PT. Fasic Indonesia untuk melakukan pelatihan yang di ikuti oleh 25 (dua puluh lima) Supervisi di PT Fasic Indonesia, dengan harapan dapat meningkat dan mengembang sesuai standar ilmu pengetahuan dan teknologi RI 4.0. yang berkualitas memiliki ketrampilan, keahlian, potensi kerja, produktivitas, disiplin, dan etos kerja.

\section{Pelaksanaan Kegiatan Pelatihan Supervisi di PT Fasic Indonesia Berdasarkan Undang-Undang Nomor 13 Tahun 2003 tentang Ketenagakerjaan Dalam Upaya Menyongsong Revolusi Industri 4.0. \\ a. Manajemen Sumber Daya Manusia (Pekerja) dan Pengorganisasian atau Perusahaan}

Konsep dasar fungsi pengorganisasian di mana struktur organisasi dibentuk, pekerjaan didesain, langkah terakhir dalam fungsi organisasi (perusahaan: penulis) adalah penempatan SDM (pekerja: penulis) ke dalam setiap bagian yang telah ditentukan dalam organisasi (perusahaan: penulis) dalam penempatan SDM (pekerja: penulis) kesetiap bagian dalam organisasi. Kegiatan ini disebut straffing (Sule \& Saefullah, 2005). Kosep dasar fungsi pengorganisasian dalam menghadapi RI 4.0 di mana struktur organisasi RI. 4.0 di PT Fasic Indonesia dibentuk, pekerjaan yang berkaitan dengan RI 4.0 didesaian, hal ini untuk memastikan pekerja yang di tempatkan disetiap Divisi dan/atau Bagian, mempunyai sikap, kompetensi, keterampilan sesuai standar RI 4.0, adapun pengertian kompetensi menurut Spencer, adalah:

"Karakteristik yang mendasari seseorang berkaitan dengan efektivitas kerja individu dalam pekerjaannya atau karakter dasar individu yang memiliki hubungan kausal atau sebab-akibat dengan kriteria yang dijadikan acuan, efektif atau berkinerja prima atau superior ditempat kerja atau pada situasi tertentu" (Moeheriono, 2014)

Mengacu kepada pengertian kompetensi dari Spencer sebagaimana dipaparkan di atas, pengertian kompetensi pekerja di PT Fasic Indonesia dalam era ilmu pengetahuan dan teknologi RI 4.0, adalah karakteristik yang mendasari seorang pekerja PT Fasic Indonesia berkaitan dengan efetivitas kerja pekerja PT Fasic Indonesia dalam pekerjaannya dalam suatu perusahaan PT Fasic Indonesia yang telah menerapkan ilmu pengetahuan dan teknologi RI 4.0 dalam usahanya atau karakter dasar pekerja PT Fasic Indonesia yang memiliki hubungan kausal atau sebab-akibat dengan kriteria yang dijadikan acuan oleh perusahaan PT Fasic Indonesia yaitu penguasaan ilmu pengetahuan dan teknologi RI 4.0, sehingga efektif atau bekineria prima atau superior dalam penguasaan ilmu pengetahuan dan teknologi RI 4.0 atau pada situasi dimana 
perusahaan PT Fasic Indonesia dalam usahanya menerapkan ilmu pengetahuan dan teknologi RI 4.0.

Dalam fungsi perencanaan tujuan dan rencana disusun. Untuk mencapai tujuan dan merealisasikan rencana, maka fungsi pengorganisasian (PT Fasic Indonesia) didesain sebuah struktur organisasi (PT Pasic Indonesia) yang di dalam berbagai sumber daya dimiliki oleh organisasi (PT Pasic Indonesia) dialokasikan beserta tugas-tugas yang akan dijalankan menurut bagian-bagian yang terdapat dalam organisasi (PT Fasic Indonesia)(Sule \& Saefullah, 2005). Langkah berikutnya adalah menentukan siapa-siapa yang akan ditempatkan pada setiap bagian dari struktur organisasi (PT Fasic Indonesia) yang telah dibentuk tersebut atau bagaimana kita (PT Fasic Indonesia) mendapat SDM (Supervisi) yang tepat untuk ditempatkan pada setiap bagian dari struktur organisasi (PT Fasic Indonesia) sehingga mendapatkan orang-orang (Supervisi) yang tepat untuk menjalankan kegiatan organisasi (PT Fasic Indonesia) sehingga tujuan organisasi (PT Fasic Indonesia) dapat tercapai secara efektif dan efesien (Sule \& Saefullah, 2005).

Peranan SDM (pekerja PT Fasic Indonesia) dalam perusahaan (PT Fasic Indonesia) memiliki peran serta fungsi yang penting bagi tercapainya tujuan organisasi perusahaan (PT Fasic Indonesia). SDM (pekerja PT Fasic Indonesia) disini mencakup keseluruhan manusia yang ada di dalam organisasi perusahaan (PT Fasic Indonesia), yaitu mereka yang secara keseluruhan terlibat dalam operasionalisasi bisnis perusahaan, dari level yang paling bawah, seperti satpam, pekeria di bagian pemrosesan barang untuk jenis perusahaan produksi, atau juga tenaga penjual (direct seller) hingga ke posisi direktur utama (Chief Executif Officer) yang menempati level teratas dalam bisnis perusahaan. Sekalipun berbeda level, akan tetapi kesemua SDM (pekerja PT Fasic Indonesia) tersebut memiliki peran yang sama dan signifikan bagi tercapai tidaknya tujuan perusahaan (PT Fasic Indonesia). Pengabaian terhadap salah satu bagian dari SDM (pekerja PT Fasic Indonesia) tersebut akan berimplikasi serius terhadap terhambatnya tercapainya tujuan perusahaan. Pengertian ini mencakup dari memulai memilih siapa saja yang pantas untuk memiliki kualifikasi seperti yang disyaratkan perusahaan hingga bagaimana agar kualifikasi ini dapat dipertahankan bahkan dapat ditingkatkan serta dikembangkan dari waktu kewaktu sehingga PT Fasic Indonesia dapat tetap kompetitif dalam persaingan global pada era RI 4.0, salah satunya melalui pengembangan pekerja PT Fasic Indonesia melalui sarana pelatihan kerja, antara lain untuk level Supervisi yang berkaitan dengan pengetahuan (knowledge), keahlian (skills) tentang ilmu pengetahuan teknologi RI 4.0 (Sule \& Saefullah, 2005).

\section{b. Pelatihan Keria di PT Pasic Indonesia}

Pelatihan kerja, adalah keseluruhan kegiatan untuk memberi, memperoleh, meningkatkan, serta mengembangkan, potensi kerja, produktivitas, disiplin, dan etos kerja pada tingkat ketrampilan dan keahlian tertentu sesuai jenjang dan kualifikasi jabatan atau pekerja (Vide Pasal 1 angka 9 Undang-Undang Nomor 13 Tahun 2003 tentang Ketenagakerjaan, selanjutnya disebut UUK). Korelasi pelatihan kerja dengan ilmu pengetahuan dan teknologi RI 4.0, adalah keseluruhan kegiatan untuk memberi, memperoleh, meningkatkan, serta mengembangkan, potensi keria, produktivitas, disiplin, dan etos kerja para Supervisi di PT Fasic Indonesia pada tingkat ketrampilan dan keahlian tertentu sesuai jenjang dan kualifikasi jabatan Supervisi yang menjadi tuntutan ilmu pengetahuan dan teknologi RI 4.0. Produktivitas kerja pegawai (pekerja PT Fasic Indonesia), adalah:

"Perbandingan hasil yang dicapai dan peran serta pegawai (PT Fasic Indonesia) per satuan waktu. Atau sejumlah barang/jasa yang dapat dihasilkan seseorang/ sekelompok orang/pegawai (pekerja PT Fasic Indonesia) dalam jangka waktu tertentu (per jam, per hari, per bulan, per triwulan, per semester, per tahun: 
penulis) pada suatu perusahaan PT Fasic Indonesia yang menggunakan ilmu pengetahuan teknologi RI 4.0 pada usahanya atau proses produksinya (Sedarmayanti, 2017).

Menurut Malayu S.P. Hasibuan, "produktivitas kerja, adalah perbandingan antara output dengan input, dimana outputnya harus mempunyai nilai tambah dan teknik pengerjaannya yang lebih baik". Korelasinya dengan teknologi RI 4.0 adalah perbandingan antara output dengan input, menggunakan teknologi RI 4.0, dimana output harus mempunyai nilai tambah dengan teknik pengerjaannya yang lebih baik, lebih efektif, efisien dalam mencapai target (goal) perusahaan baik target secara kuantitas dan kualitas (Hasibuan, 2012).

Disiplin kerja, adalah "pekerja/buruh mampu mematuhi peraturan-peraturan yang ada dan melakukan pekerjaannya sesuai instruksi yang diberikan kepadanya atau sesuai perkembangan ilmu pengetahuan dan teknologi RI 4.0 sehingga perusahaan lebih maju, produktif dan kompetitif dalam persaingan global" (Hasibuan, 2012)

Etos kerja atau semangat kerja, adalah:

"Keinginan dan kesungguhan seseorang mengerjakan pekerjaannya dengan baik serta berdisiplin untuk mencapai prestasi kerja yang maximal. Semangat kerja ini akan merangsang seseorang untuk berkarya dan berkreativitas dalam pekerjaannya pada suatu perusahaan yang proses produksinya menggunakan teknologi RI 4.0 "(Hasibuan, 2012).

Keahlian (skill) atau ketrampilan, yaitu:

"Kemampuan untuk melaksanakan tugas tertentu baik secara fisik maupun mental" misalnya seorang programer computer mempunyai ketrampilan dapat menginput atau mengorganisasikan 100.000 (seratus ribu) kode data dalam logika dan pikirannya dengan waktu tertentu, atau seorang pengetik dapat mengetik surat 50 (lima puluh) buah perhari (Moeheriono, 2014)

Setiap pekerja berhak untuk memperoleh, meningkatkan dan/atau mengembangkan kompetensi kerja sesuai dengan bakat, minat, dan kemampuannya melalui pelatihan kerja (Vide Pasal 11 UUK). Kompetensi, adalah:

"Karakteristik yang mendasari seseorang berkaitan dengan efektivitas kinerja individu dalam pekerjaannya atau karakteristik dasar individu yang memiliki hubungan kausal atau sebagai sebab-akibat dengan kriteria yang dijadikan acuan, efektif atau berkineria prima atau suporior ditempat kerja atau pada situasi tertentu (Moeheriono, 2014).

Menurut (Moeheriono, 2014), berdasarkan dari arti definisi kompetensi ini, maka banyak mengandung beberapa makna yang terkandung di dalamnya, adalah sebagai berikut:

1) Karakteristik dasar kompetensi, adalah bagian dari kepribadian yang mendalam dan melekat pada seseorang serta mempunyai prilaku yang dapat diprediksi pada berbagai keadaan tugas pekerjaan (termasuk pada suatu perusahaan yang proses produksinya menggunakan teknologi RI 4,0 : penulis).

2) Hubungan kausal, berarti kompetensi dapat menyebabkan atau digunakan untuk memprediksi kinerja seseorang, artinya bila mempunyai kompetensi yang tinggi maka akan mempunyai kinerja yang tinggi pula/sebagai akibat atau apabila $\mathrm{SDM} /$ pekeria mempunyai kompetensi yang tinggi dalam bidang teknologi RI 4.0, maka akan mempunyai kinerja yang tinggi pula pada proses produksi yang menggunakan teknologi RI 4.0.

3) Kriteria yang dijadikan acuan, bahwa kompetensi secara nyata akan memprediksikan seseorang dapat bekerja dengan baik, harus terukur dan spesifik atau terstandar, misalnya kriteria volume penjualan yang mampu dihasilkan seseorang salesmen sebesar 1000 buah/bulan atau seorang manajer keuangan 
dapat memperoleh keuntungan 1 (satu) miliar/tahun (seorang atau sekelompok pekerja mampu bekerja pada perusahaan yang telah menggunakan teknologi RI 4.0 pada proses produksinya: penulis).

Tenaga kerja sebagai pelaku (subjek) pembangunan, sekaligus sebagai tujuan pembangunan, berperan meningkatkan produktivitas nasional dan kesejahteraan masyarakat, untuk itu pekerja harus diberdayakan agar memiliki kemampuan dan nilai lebih serta berdaya saing tinggi (dalam persaingan global di era perkembangan teknologi RI 4.0: penulis). Untuk mencapai hal tersebut diperlukan pembinaan secara terarah dan berkelanjutan dengan materi pembinaan sesuai tuntutan perkembangan ilmu pengetahuan dan teknologi RI 4.0 dan berdasarkan tujuan pembangunan ketenagkerjaan, yaitu mewujudkan manusia dan masyarakat Indonesia yang sejahtera, adil, makmur, merata, baik materiil maupun spiritual (Abdul, 2014).

"Pembangunan ketenagakerjaan dilaksanakan dalam rangka pembangunan manusia seutuhnya. Oleh sebab itu, pembangunan ketenagakerjaan dilaksanakan untuk mewujudkan manusia dan masyarakat Indonesia yang sejahtera, adil, makmur, merata, baik materiil maupun spiritual (Vide penjelasan Pasal 2 UUK)"

Produktivitas, adalah ukuran efesiensi dan efektivitas input (manusia/pekerja, mesin/teknologi, meterial/bahan baku, metoda, money, market) menjadi output (jumlah unit produk, pendapatan, keuntungan, hasil barang/jasa) dimana output lebih besar dari input. Produktivitas tinggi apabila input lebih rendah dari output atau sebaliknya.

Pelatihan kerja adalah untuk membekali, meningkatkan, dan mengembangkan kompetensi kerja guna meningkatkan kemampuan, produktivitas, dan kesejahteraan bagi tenaga kerja (pekerja: penulis). Upaya pembinaan tenaga kerja (pekerja: penulis) ditempuh melalui perencanaan dan program ketenagakerjaan, seperti pelatihan, pemagangan, dan pelayanan penempatan kerja (Abdul, 2014). Program pelatihan kerja juga bertujuan menyiapkan tenaga kerja (pekerja: penulis) untuk mengisi (promosi: penulis) atau mengisi kesempatan/lowongan keria terutama pada perusahaan yang proses produksinya menerapkan teknologi RI 4.0. (Abdul, 2014)

Pasal 10 ayat (1), ayat (1), Pasal 12 ayat (1), ayat (3), Pasal 13 ayat (1), Pasal 14 ayat (1), ayat (2), ayat (3) UUK, mengatur mengenai pelatihan keria, sebagai berikut:

a) Penyelenggaraan pelatihan kerja, dapat lembaga pelatihan kerja pemerintah dan/atau swasta dan untuk lembaga pelatihan kerja swasta dapat berbentuk badan hukum indonesia atau perorangan serta wajib mendapatkan izin atau mendaftar kepada instansi yang bertanggung jawab di bidang ketenagakerjaan di kabupaten/kota, sementara untuk lembaga pelatihan kerja pemerintah mendaftarkan kegiatannya kepada instansi yang bertanggung jawab di bidang ketenagakerjaan di kabupaten/kota. Dalam rangka RI 4.0, menurut penulis, sebaiknya salah satu syarat lembaga pelatihan kerja mendapat izin sebagai menyelenggarakan pelatihan kerja, lembaga pelatihan kerja tersebut harus memiliki kurikulum yang berkaitan dengan ilmu pengetahuan dan teknologi RI4, memiliki instruktur (pelatih) yang menguasai ilmu pengetahuan dan teknologi RI 4.0 dan memiliki sarana, alat, peraga pelatihan yang sesuai standar RI 4.0.

b) Pelaksanaan pelatihan kerja harus memperhatikan kebutuhan pasar kerja dan dunia usaha (yang berkorelasi dengan perkembangan ilmu pengetahuan dan teknologi/RI 4.0: penulis).

c) Tempat pelatihan kerja dapat di dalam atau di luar hubungan kerja.

d) Pelatihan kerja harus mengacu kepada standar kompetensi kerja (yaitu standar kompetensi kerja yang sesuai perkembangan ilmu pengetahuan dan teknologi RI 4.0: penulis). 
e) Pengusaha bertanggung jawab atas peningkatan dan/atau pengembangan kompetensi pekerja (juga dalam peningkatan dan/atau pengembangan kompetensi pekeria sesuai tututan ilmu pengetahuan dan teknologi RI 4.0: penulis).

f) Sesuai dengan tugasnya setiap pekerja memiliki kesempatan yang sama untuk mengikuti pelatihan keria sehingga setiap pekerja memiliki kompetensi, keterampilan (skill), terutama yang berkaitan dengan ilmu pengetahuan dan/atau teknologi (RI 4.0).

Menurut Pasal 15 UUK, penyelenggara pelatihan kerja wajib memenuhi syarat: (i). Tersedianya tenaga kepelatihan (instruktur). (ii). Adanya kurikulum yang sesuai dengan tingkat pelatihan. (iii) Tersedianya sarana dan prasarana pelatihan kerja, dan. (iv). Tersedianya dana untuk kelangsungan kegiatan penyelenggaraan pelatihan kerja. Mengacu kepada Pasal 15 UUK, penyelenggara pelatihan kerja dalam era teknologi RI 4.0, wajib memenuhi syarat: (i). Tersedianya tenaga pelatih (instruktur) yang mengusai teknologi RI 4.0. (ii). Adanya kurikulum yang sesuai dengan tuntutan teknologi RI4. (iii). Tersedianya sarana dan prasarana pelatihan kerja sesuai dengan teknologi RI 4.0. (iv). Tersedianya dana untuk kelangsungan kegiatan pelatihan kerja teknologi RI 4.0.

Menurut kepada Pasal 21, Pasal 22 ayat (1), ayat (2), ayat (3) UUK, mengatur pelatihan keria dapat diselenggarakan dengan sistem pemagangan yang dilaksanakan atas dasar perjanjian pemagangan secara tertulis antara peserta dan pengusaha. Perjanjian pemagangan memuat ketentuan hak dan kewajiban antara peserta dan pengusaha, serta jangka waktu pemagangan. Tanpa adanya perjanjian pemagangan, maka pemagangan dianggap tidak sah dan status peserta berubah menjadi pekerja perusahaan yang bersangkutan. Hak peserta pemagangan, adalah memperoleh uang saku dan/atau transport, jaminan sosial tenaga kerja, dan sertifikat setelah lulus program. Hak pengusaha, adalah hasil kerja/jasa peserta pemagangan, apabila memenuhi persyaratan, merekrut pemagang sebagai pekerja diperusahaan tersebut. Kewajiban peserta pemagangan, adalah mentaati perjanjian pemagangan, mengikuti tata tertib program pemagangan dan tata tertib perusahaan. Kewajiban pengusaha, antara lain menyediakan uang saku dan/atau vang transport bagi peserta pemagangan, menyediakan fasilitas pelatihan, menyediakan instruktur, dan menyediakan perlengkapan keselamatan dan kesehatan kerja.

\section{c. Pelatihan dan Pengembangan di PT Fasic Indonesia}

Pelatihan dan pengembangan (training and development) adalah jantung dari upaya berkelanjutan untuk meningkatkan kopetensi karyawan (para pekerja PT Fasic Indonesia) dan kinerja organisasi (PT Fasic Indonesia). Pelatihan memberi para pembelajar pengetahuan dan ketrampilan yang dibutuhkan untuk pekerjaan mereka (para pekerja PT Fasic Indonesia: penulis) saat ini. Menunjukan kepada karyawan (para pekerja PT Fasic Indonesia: penulis) cara mengoperasikan mesin produksi (termasuk mesin produksi berteknologi RI 4.0: penulis) atau kepada supervisor cara menjadwalkan produksi harian (berdasarkan teknologi RI 4.0: penulis) itulah merupakan contoh-contoh pelatihan dalam RI 4.0.

Pengembangan melibatkan pembelajaran yang melampaui pekerjaan saat ini dan memiliki fikus jangka panjang. Pengembangan mempersiapkan para karyawan untuk tetap sejalan dengan perubahan dan pertumbuhan organisasi. Aktivitas-aktivitas pelatihan pelatihan dan pengembangan memiliki potensi untuk menyelaraskan para karyawan (pekerja: penulis) dengan strategi-strategi perusahaan mereka. Beberapa mamfaat strategi yang mungkin diperoleh dari pelatihan dan pengembangan mencakup kepuasan karyawan (pekerja: penulis), meningkatnya semangat, tingkat rerensi yang lebih tinggi, turnover yang lebih rendah, perbaikan dalam penarikan karyawan (pekerja: penulis), hasil akhir yang lebih baik, dan kenyataan para karyawan (pekerja: 
penulis) yang puas akan menghasilkan para pelanggan yang puas. (Lacerenza et al., 2017)

Berdasarkan paparan di atas, pengembangan pekeria dalam menghadapi RI 4.0. melibatkan pembelajaran yang melampaui pekerjaan sebelum RI 4.0 dan memiliki fikus jangka penjang. pengembangan pekerja dalam menghadapi RI 4.0. adalah mempersiapkan para pekerja untuk tetap sejalan dengan perubahan dan pertumbuhan organisasi dalam era RI. 4.0. Aktivitas-aktivitas pelatihan pelatihan dan pengembangan memiliki potensi untuk menyelaraskan para pekerja dengan strategi-strategi perusahaan dalam menghadapi era RI. 4.0, dampak positifnya, terjadi kepuasan dari para pekerja, meningkatnya semangat, tingkat rerensi yang lebih tinggi, turnover yang lebih rendah, perbaikan dalam penarikan pekerja, hasil akhir yang lebih baik, dan kenyataan para pekerja yang puas akan menghasilkan para pelanggan yang puas.

Menurut (Sutrisno, 2019), pengembangan SDM (pekerja/karyawan: penulis), adalah proses persiapan individu-individu untuk memikul tanggung jawab yang berbeda atau lebih tinggi di dalam organisasi (perusahaan: penulis), biasanya berkaitan dengan peningkatan kemampuan intelektual untuk melaksanakan pekerjaan yang lebih baik. Pengembangan mengarah pada kesempatan-kesempatan belajar yang didesain guna membantu pengembangan para pekeria dalam menghadapi era RI 4.0.

Selanjutnya menurut (Sutrisno, 2019) dalam kontek SDM, pengembangan dipandang sebagai peningkatan kualitas SDM melalui program-program pelatihan, pendidikan. Pelatihan membantu karyawan (pekerja: penulis) dalam memahami suatu pengetahuan praktis dan pengetrapannya, guna meningkatkan ketrampilan, kecakapan dan sikap yang diperlukan oleh organisasi dalam usaha mencapai tujuannya dalam era RI 4.0.

Pendidikan, menurut Husnan dalam (Sutrisno, 2019) adalah suatu kegiatan untuk meningkatkan penguasaan teori dan ketrampilan memutuskan terhadap persoalanpersoalan yang menyangkut kegiatan mencapai tujuan. Upaya ini dilakukan untuk memperbaiki kontribusi produksi para karyawan (pekerja:penulis) dan mengembangkan SDM menghadapi segala kemungkinan yang terjadi akibat perubahan lingkungan (RI 4.0: Penulis). Arti pengembangan karyawan (pekerja: penulis) merupakan usaha-usaha untuk meningkatkan ketrampilan maupun pengetahuan umum bagi karyawan (pekerja: penulis) agar pelaksanaan pencapaian tujuan lebih efisien.

Menurut Husnan dalam (Sutrisno, 2019) pengembangan SDM, adalah proses pendidikan jangka panjang yang menggunakan prosedur sistimatis dan terorganisasi, sehingga tenaga kerja menejerial mempelajari pengetahuan konseptual dan teoritis untuk tujuan umum. Tujuan umum pengembangan SDM meningkatkan kualitas profesionalisme dan ketrampilan para karyawan (pekerja: penulis) dalam melaksanakan tugas dan fungsinya secara optimal. Dengan mengembangkan kecakapan karyawan (pekerja: penulis) dimaksud sebagai setiap usaha dari pimpinan untuk menambah keahlian kerja tiap karyawan (pekerja: penulis) sehingga di dalam melaksanakan tugas-tugasnya dapat lebih efesien dan produktif terutama dalam menghadapi era RI 4.0. (Sutrisno, 2019)

Menurut Edy Sutrisno, tujuan pengembangan SDM, adalah untuk meningkatkan kualitas profesionalisme dan ketrampilan para karyawan (pekerja: penulis) dalam melaksanakan tugas dan fungsinya secara optimal. Dengan mengembangkan kecakapan karyawan dimaksud sebagai setiap usaha dari pimpinan untuk menambah keahlian kerja tiap karyawan (pekerja: penulis) sehingga di dalam setiap melaksanakan tugas-tugasnya lebih efisien dan produktif, memperbaiki kapasitas produktif dari manusia, guna memiliki kekuatan kompetitif dan lebih sulit ditiru sehingga sumbersumber keberhasilan kompetitif, seperti teknologi proses produksi, proteksi pasar, akses terhadap sumber kevangan lebih berdaya guna dan berhasil guna serta kinerja karyawan (pekerja: penulis) lebih terwujud.(Sutrisno, 2019) 
Berdasarkan paparan di atas, tujuan pengembangan SDM dalam era RI 4.0, adalah meningkatkan profesionalisme dan ketrampilan para pekerja dalam melaksanakan tugas dan fungsinya secara optimal pada perusahaan yang operasionalnya sudah menggunakan ilmu pengetahuan dan teknologi RI 4.0. Dengan mengembangkan kecakapan pekerja dimaksud setiap usaha dari pimpinan untuk menambah keahlian kerja tiap pekerja, sehingga dalam setiap melaksanakan tugas-tugasnya dapat lebih efisien dan produktif, terutama dalam melaksanakan tugas-tugas yang berkaitan dengan operasional yang menggunakan ilmu pengetahuan dan teknologi RI 4.0, memperbaiki kapasitas produktif dari manusia yang berkaitan dengan operasional perusahaan yang menggunakan ilmu pengetahuan dan teknologi RI 4.0, guna memiliki kekuatan kompetitif dan lebih sulit ditiru sehingga sumber-sumber keberhasilan kompetitif, seperti teknologi proses produksi, proteksi pasar, akses terhadap sumber keuangan yang berdasarkan ilmu pengetahuan dan teknologi RI 4.0, lebih berdaya guna dan berhasil guna serta kinerja pekerja lebih terwujud.

Tujuan pengembangan menurut (Hasibuan, 2012), hakikatnya menyangkut hal-hal sebagai berikut:

a) Produktivitas kerja, dengan pengembangan produktivitas kerja karyawan akan meningkat kualitas dan kuantitas produksi semakin baik, karena technical skill, human skill dan managerial skill karyawan (pekerja:penulis) yang semakin baik.

b) Efesiensi, pengembangan karyawan bertujuan untuk meningkatkan efesiensi tenaga, waktu, bahan baku, dan mengurangi ausnya mesin-mesin, mengurangi pemborosan, biaya produksi relatif kecil sehingga daya perusahaan semakin besar.

c) Kerusakan, pengembangan karyawan bertujuan untuk mengurangi kerusakan barang, produksi dan mesin-mesin karena karyawan (pekerja:penulis) semakin ahli dan trampil dalam melaksanakan pekerjaannya.

d) Kecelakaan, pengembangan karyawan bertujuan untuk mengurangi kecelakaan karyawan (pekerja:penulis) sehingga jumlah biaya pengobatan yang dikeluarkan perusahaan berkurang.

e) Pelayanan, pengembangan karyawan bertujuan untuk meningkatkan pelayanan yang lebih baik dari karyawan (pekerja: penulis) kepada nasabah perusahaan, karena pemberian pelayanan yang baik, merupakan daya penarik yang sangat penting bagi rekan-rekanan perusahaan yang bersangkutan.

f) Moral, dengan pengembangan, moral karyawan (pekerja: penulis) akan lebih baik karena keahlian dan ketrampilannya sesuai dengan pekerjannya sehingga mereka antuas untuk menyelesaikan pekerjaan dengan baik.

g) Karier, dengan pengembangan karywan, kesempatan utnuk meningkatkan karier karyawan semakin besar, karena keahlian, ketrampilan, dan prestasi kerjanya lebih baik. Promosi ilmiah biasanya didasarkan pada keahlian dan prestasi kerja seseorang.

h) Konseptual, dengan pengembangan, manajer semakin cakap dan cepat mengambil keputusan yang lebih baik, karena technical skill, human skill dan manajerial skill-nya lebih baik.

i) Kepemimpinan, kepemimpinan seorang manajer akan lebih baik human relationsnya lebih luwes, motivasinya lebih terarah sehingga pembinaan kerjasama vertikal dan horizontal semakin harmonis.

i) Balas jasa, dengan pengembangan, balas jasa (gaji, upah insentif, dan benefits) karyawan akan meningkat karena prestasi kerja mereka semakin besar.

k) Konsumen, pengembangan karyawan akan memberikan mamfaat yang baik bagi masyarakat konsumen, karena mereka akan memperoleh barang dan pelayanan yang lebih bermutu. 


\section{PENUTUP}

Pengembangan SDM di PT Fasic Indonesia, adalah proses pendidikan jangka panjang yang menggunakan prosedur sistimatis dan terorganisasi, sehingga para supervisi di PT Fasic Indonesia dapat mempelajari pengetahuan konseptual dan teoritis untuk tujuan umum. Tujuan umum pengembangan SDM di di PT Fasic Indonesia, adalah upaya meningkatkan kualitas profesionalisme dan ketrampilan para supervisi di PT Fasic Indonesia dalam melaksanakan tugas dan fungsinya secara optimal. Dengan mengembangkan kecakapan para supervisi di PT Fasic Indonesia dimaksud sebagai setiap usaha dari pimpinan PT Fasic Indonesia untuk menambah keahlian kerja para supervisi sehingga di dalam melaksanakan tugas-tugasnya dapat lebih efesien dan produktif terutama dalam menyongsong era RI 4.0.

Pelatihan dan pengembangan (training and development) adalah jantung dari upaya berkelanjutan untuk meningkatkan kopetensi para supervisi PT Fasic Indonesia dan kinerja PT Fasic Indonesia. Pelatihan memberi para supervisi pengetahuan dan ketrampilan yang dibutuhkan untuk pekerjaan para supervisi saat ini. Menunjukan kepada para supervisi PT Fasic Indonesia, antara lain cara mengoperasikan mesin produksi berteknologi RI 4.0 atau kepada para supervisi cara menjadwalkan produksi harian berdasarkan teknologi RI 4.0. Pengembangan para supervisi di PT Fasic Indonesia melibatkan pembelajaran yang melampaui pekerjaan saat ini dan memiliki fikus jangka panjang. Pengembangan mempersiapkan para supervisi di PT Fasic Indonesia untuk tetap sejalan dengan perubahan dan pertumbuhan organisasi. Aktivitasaktivitas pelatihan pelatihan dan pengembangan memiliki potensi untuk menyelaraskan para supervisi dengan strategi-strategi PT Fasic Indonesia. Beberapa mamfaat strategi yang mungkin diperoleh dari pelatihan dan pengembangan mencakup kepuasan khususnya para supervisi dan umumnya para pekerja PT Fasic Indonesia demi meningkatkan semangat, tingkat rerensi yang lebih tinggi, turnover yang lebih rendah, perbaikan dalam penarikan para pekerja, hasil akhir yang lebih baik, dan kenyataan khususnya para supervisi dan umumnya para pekerja PT Fasic Indonesia yang merasa puas akan menghasilkan para pelanggannya yang juga puas, sehingga akan terjamin keberlanjutan usaha PT Fasic Indonesia dan keberlanjutan bekerja para pekerjanya.

Mengingat pelatihan dan pengembangan (training and development) merupakan jantung dari upaya berkelanjutan untuk meningkatkan kopetensi para supervisi PT Fasic Indonesia dan kineria PT Fasic Indonesia, yang berkaitan dengan kepuasan-kepuasan dari: para supervisi, para pekerja dan para pelanggannya dan berujuang terjamin keberlanjutan usaha PT Fasic Indonesia dan keberlanjutan bekerja para pekerjanya, terutama dalam menghadapi era RI 4.0, maka pelatihan dan pengembangan (training and development) yang berkaitan dengan ilmu pengetahuan dan teknologi 4.0 di PT Fasic Indonesia, harus dilakukan secara matang mulai dari perancanaan, pelaksanaan dan evaluasi keberhasilannya, untuk itu PT Fasic Indonesia harus melakukan langkahlangkah: (i).Mengidentifikasi dari tujuan yang diinginkan dari pelatihan dan/atau kebutuhan pelatihan (training need), (ii). Taktik atau strategi dari berbagai langkah untuk mencapai tujuan yang diinginkan dari pelatihan. (iii). Penyediaan berbagai input untuk memungkinkan pelaksanaan secara nyata dari taktik atau strategi pelatihan. (iv). Peserta pelatihan. (v). Jadwal pelatihan. (vi). Pelaksanaan pelatihan. (vii).Evaluasi tentang efektifitas pelaksanaan pelatihan. Semua langkah-langkah pelatihan sebagaimana dipaparkan di atas harus disesuaikan dengan standar ilmu pengetahuan dan teknologi 4.0 terutama yang berkaitan dengan aspek-aspek: produktivitas kerja, efesiensi, efektifitas, kerusakan, kecelakaan, pelayanan, moral, karier, konseptual, kepemimpinan, balas jasa dan konsumen PT Fasic Indonesia.

Maksud Penyediaan berbagai input untuk memungkinkan pelaksanaan secara nyata dari taktik atau strategi pelatihan sebagaimana dipaparkan di atas (huruf iii), yaitu 
mulai dari perumusan sampai evaluasi dari suatu pelatihan (huruf i s/d huruf vii) secara partisipatif dan emansipatif harus melibatkan semua elemen dari para supervisi di PT Fasic Indonesia, dan langkah-langkah pelatihan para supervisi harus merupakan hasil pembahasan dan kesepakatan bersama antara para supervisi dan PT Fasic Indonesia.

\section{E. UCAPAN TERIMA KASIH}

Penulis ucapkan terima kasih kepada Rektor Universitas Suryakancana, Direktur Pascasarjana Universitas Suryakancana, Ketua LPPM Universitas Suryakancana, dan tak lupa kepada Direksi PT. Fasic Indonesia yang bersedia bekerja sama dalam memberikan pelatihan kepada para supervisi.

\section{F. DAFTAR PUSTAKA}

Abdul, K. (2014). Dasar-Dasar Hukum Ketenagakerjaan Indonesia. Citra Aditya Bakti.

Fonna, N. (2019). Pengembangan Revolusi Industri 4.0 dalam Berbagai Bidang. Guepedia.

Hasibuan, M. (2012). Manajemen Sumber Daya Manusia (Revisi). Bumi Aksara.

Lacerenza, C. N., Reyes, D. L., Marlow, S. L., \& Joseph, D. L. (2017). Supplemental Material for Leadership Training Design, Delivery, and Implementation: A MetaAnalysis. Journal of Applied Psychology, 102(12), 1686-1718. https://doi.org/10.1037/apl0000241.supp

Moeheriono, P. (2014). Pengukuran Kinerja Berbasis Kompetensi Edisi Revisi. PT Rajagrafindo Persada.

Sedarmayanti. (2017). Perencanaan dan Pengembangan Sumber Daya Manusia. Refika Aditama.

Sule, E. T., \& Saefullah, K. (2005). Pengantar Manajemen, edisi pertama, cetakan pertama. Prenada Media.

Sutrisno, E. (2019). Manajemen sumber daya manusia. Kencana. 